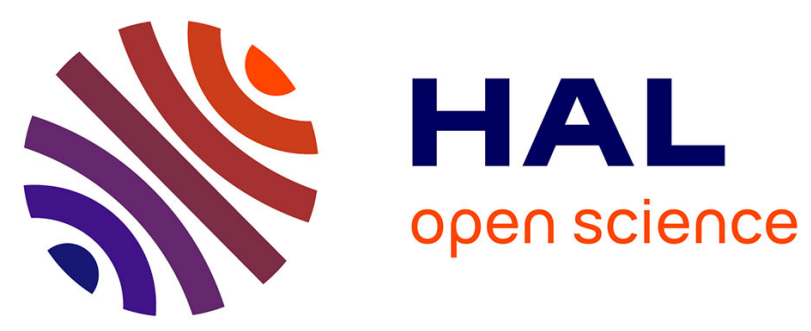

\title{
Impacts that cause the highest direct mortality of individuals do not necessarily have the greatest influence on temperate eel escapment
}

\author{
Maria Mateo, Patrick Lambert, Stéphane Tétard, Hilaire Drouineau
}

\section{- To cite this version:}

Maria Mateo, Patrick Lambert, Stéphane Tétard, Hilaire Drouineau. Impacts that cause the highest direct mortality of individuals do not necessarily have the greatest influence on temperate eel escapment. Fisheries Research, 2017, 193, pp.51-59. 10.1016/j.fishres.2017.03.024 . hal-01728986

\section{HAL Id: hal-01728986 \\ https://hal.science/hal-01728986}

Submitted on 12 Mar 2018

HAL is a multi-disciplinary open access archive for the deposit and dissemination of scientific research documents, whether they are published or not. The documents may come from teaching and research institutions in France or abroad, or from public or private research centers.
L'archive ouverte pluridisciplinaire HAL, est destinée au dépôt et à la diffusion de documents scientifiques de niveau recherche, publiés ou non, émanant des établissements d'enseignement et de recherche français ou étrangers, des laboratoires publics ou privés. 
1 Impacts that cause the highest direct mortality of individuals do not necessarily have the greatest

2 influence on temperate eel escapement

3 Maria Mateo ${ }^{1}$, Patrick Lambert ${ }^{1}$, Stéphane Tétard ${ }^{2}$, and Hilaire Drouineau ${ }^{1}$

4

6

\section{Abstract}

\section{Keywords:}

${ }^{1}$ Irstea, UR EABX Ecosystèmes aquatiques et changements globaux, HYNES Irstea-EDF R\&D, 50 avenue de Verdun, 33612 Cestas, France

2 EDF R\&D, HYNES Irstea-EDF R\&D, Laboratoire National d'Hydraulique et Environnement'6 quai Watier, 78401 Chatou, France

Temperate eels are three panmictic catadromous species with a long period of oceanic passive larval drift and large distribution areas in contrasting environments. Spatial patterns of life history traits have been observed, and are correlated with environmental gradients, and may arise from both adaptive phenotypic plasticity and genetic polymorphism. This raises the question of the effect of spatially heterogeneous anthropogenic pressures on these populations. In this context, we used Geneveel, an individual-based optimization model that includes both phenotypic plasticity and genetic polymorphism, to explore the effects of different kinds of anthropogenic pressures: glass eel and silver eel fisheries, obstacles to upstream migration, and turbine mortality. More specifically, we analyzed the effects of these pressures on five output variables: the number of escapees, the proportion of females, the proportion of slow growers, the mean length-at-silvering and the resulting egg production. Our results suggest that phenotypic plasticity could act as a compensatory mechanism that mitigates the effects of some pressures (glass eel fishery and obstacles to upstream migration) and could be a source of resilience for the population, while other pressures did not show any compensatory effect (silver eel fishery and turbine mortality). Therefore, global impacts are very hard to assess, and the pressure that kills the most individuals does not necessarily have the biggest impact on the spawning biomass.

Temperate eels; anthropogenic pressures; adaptive mechanisms; life history traits; modeling

Corresponding author: Maria Mateo

Phone number: +33 (0)5 57890998

Email: maria.mateo@irstea.fr 


\section{Introduction}

Temperate eels (Anguilla rostrata, A. anguilla, A. japonica) are three catadromous species that reproduce at sea and grow in continental waters. They display remarkable similarities in life history traits (Daverat et al., 2006; Edeline, 2007). The three populations are panmictic (Als et al., 2011; Han et al., 2010; Pujolar, 2013). Reproduction occurs in the Sargasso Sea for A. anguilla and A. rostrata (McCleave, 1993; Schmidt, 1923) and west of the Mariana Islands for A. japonica (Tsukamoto, 1992). Larvae (known as leptocephali) are subject to a long and passive trans-oceanic drift. When arriving on the continental shelves, leptocephali metamorphose into young and transparent eels, called glass eels (Tesch, 2003), and enter continental waters, where they become pigmented yellow eels, the immature adult stage. After a variable period, generally lasting from three to 15 years, yellow eels metamorphose again into silver eels (this metamorphosis is generally called "silvering"), the seaward migration stage. They achieve their sexual maturation while migrating back to spawning grounds. Because of the long larval drift, their distribution area is very large, and the growth phase can occur in very heterogeneous river basins, from Morocco to Norway (Tesch, 2003) for the European eel, from Venezuela to Greenland for A. rostrata (Helfman et al., 1987), and from the northern Philippines to Korea for A. japonica (Tsukamoto, 1992).

Concomitantly to this environmental heterogeneity, temperate eels display remarkable life history trait patterns at both distribution and river catchment scales (Vélez-Espino and Koops, 2009). Among them, the sex ratio is highly variable at different spatial scales: female-biased sex ratios are generally observed in the northern part of the distribution area, while male-biased sex ratios are observed in the southern part (Kettle et al., 2011). At the catchment scale, sex ratios are male biased in downstream habitats (Oliveira and Mccleave, 2000; Tesch, 2003). This question of sex ratio is relevant since eel sex is not genetically determined, but depends on environmental conditions (Davey and Jellyman, 2005; Geffroy, 2012; Geffroy and Bardonnet, 2015), and males and females display very different life history tactics (Helfman et al., 1987). Males are assumed to have a time-minimizing strategy; since their reproductive success does not depend on their size, they are assumed to leave continental waters as soon as they reach the minimal size required to successfully migrate back to spawning grounds (Oliveira, 1999; Van Den Thillart et al., 2007; Vollestad, 1992). On the other hand, female reproductive success is assumed to be a trade-off between size at maturity (known as length-at-silvering) and survival, called a size-maximizing strategy. This size-maximizing strategy assumption is supported by the observation of larger females in the northern part of the distribution area (slow growth but lower mortality) than in the southern part (Davey and Jellyman, 2005; Helfman et al., 1984).

Indeed, eels display a large range of tactics in terms of habitat use for growth, with some settling in estuarine waters, while others moving far upstream in river catchments (Arai and Chino, 2012; Daverat et al., 2006; Tsukamoto et al., 1998). Higher densities are observed in downstream habitats, which are the most accessible and the most favorable in terms of growth rates (Daverat et al., 2012; Helfman et al., 1984; Melià et al., 2006). However, other eels also settle in the upper parts of river catchments. Edeline (2007) proposed that more limited intraspecific competition may overcome migratory energy costs, such as loss in growth rate. This assumption was challenged by Cairns et al. (2009), who did not observe a decrease in natural mortality in upstream habitats that would outweigh the cost of migration and the decrease in growth rate.

Few studies have explored whether the observed spatial phenotypic patterns are the result of adaptive mechanisms to environmental variability, and they therefore remain poorly understood. The panmixia and long and passive larval drifts impair the possibility of local adaptation. Phenotypic plasticity has been proposed as an adaptive response to environment variability for many species (Gotthard and Nylin, 1995; Levins, 1963; Pigliucci, 2005), and Ernande and Dieckmann (2004) demonstrated that density dependence favors the selection of plastic phenotypes. In this context, assuming that phenotypic plasticity is an adaptive response to environmental variability, Drouineau et al. (2014) developed an optimization model that was able to mimic most of 
the observed patterns at both the distribution area and river catchment scales. The existence of correlations between genotypic patterns and environmental conditions have been observed (Boivin et al., 2015; Côté et al., 2015, 2014, 2009; Gagnaire et al., 2012; Pujolar et al., 2014; Ulrik et al., 2014). Côté et al. (2014, 2009) and Boivin et al. (2015) observed differences in growth rates depending on eel origin that were preserved after several months in common garden experiments. Pujolar et al. (2014), Gagnaire et al. (2012) and Ulrik et al. (2014) observed patterns in singlenucleotide polymorphisms correlated with environmental conditions. They assumed that individual genetic differences contribute to the emergence of phenotypic spatial patterns because of differential selection by the environment, but that these differences are reshuffled in each generation because of panmixia. In this context, Mateo et al. (in press) developed a new model, called GenEveel, that was able to mimic all observed patterns assuming the existence of genetic polymorphism in growth rate and adaptive phenotypic plasticity. It suggested that the genetic polymorphism and phenotypic plasticity may have been selected by natural selection as an adaptation to environmental heterogeneity and density dependence. In this context, selection of growth habitats, length-atsilvering and sex determination would be plastic traits that enable individuals to optimize their fitness in a wide range of environments.

This issue of adaptation to environmental variability is presently crucial because temperate eels have suffered dramatic collapses (Dekker, 2009; Dekker and Casselman, 2014; Jacoby et al., 2015), and A. anguilla is classified as critically endangered by the IUCN (Jacoby and Gollock, 2014a), while A. rostrata and A. japonica are classified as endangered (Jacoby et al., 2014; Jacoby and Gollock, 2014b). Several factors have been proposed to explain these declines (Jacoby et al., 2015), including changes in oceanic conditions (Castonguay et al., 1994), contamination and habitat degradation (Belpaire et al., 2016; Byer et al., 2015), parasitism (Feunteun, 2002; Kirk, 2003), fishing pressure (Dekker, 2003a), fragmentation including massive habitat loss (Kettle et al., 2011), and hydroelectricity-induced mortality (Castonguay et al., 1994). In view of this situation, the European Commission introduced European Regulation $N^{\circ} 1100 / 2007$, imposing a new set of measures designed to reverse the decline. Since eel management is under the responsibility of member states, each member state was required to implement Eel Management Plans, enforcing management measures to decrease all sources of anthropogenic mortalities. Because of the heterogeneity in anthropogenic pressures, these measures are quite heterogeneous, targeting different types of pressures among countries and regions. The impact of anthropogenic pressures is indeed generally assessed by quantifying the induced mortality rates. Indeed, the European Regulation uses the biomass of escapees as a management target (the Regulation required that management measures should be implemented to ensure that silver eel escapement is at least $40 \%$ of the escapement in pristine conditions). However, in the presence of genetic polymorphism and phenotypic plasticity, anthropogenic pressures can have a wide range of effects in terms of life history traits. They can be a selective pressure advantaging fast or slow growers or have consequences in terms of the sex ratio, length-at-silvering or spatial distribution by affecting plastic traits.

In view of this, we decided to use GenEveel (Mateo et al., in press) to assess the impact of anthropogenic pressures on silver eel escapement, not only by quantifying the number of escapees, but also by assessing their effect on the sex ratio, the proportions of slow and fast growers, the length-at-silvering and the resulting egg production after a generation in continental waters exposed to different kinds of anthropogenic pressures. We chose to focus on four kinds of anthropogenic pressures: (i) the glass eel fishery, (ii) obstacles to upstream migration, (iii) turbine mortality during downstream migration, and (iv) the silver eel fishery. (i) Glass eel fishing is a widespread activity in France, the UK, Spain, Portugal and Italy (ICES, 2016), in some North American rivers (Cairns et al., 2008; Dutil et al., 2009; Jessop, 1998) and in Asian waters (Tatsukawa, 2003). In the Bay of Biscay, the glass eel fishery used to be the most important fishery in France in terms of turnover (Castelnaud, 2000), and the Bay of Biscay is assumed to receive the main part of the total 
recruitment (Dekker, 2000). These fisheries harvest young, sexually undetermined individuals entering continental waters. In some river basins, the glass eel fishery can catch nearly all individuals entering the basins, such as in the Vilaine River, where the recruitment rate is less than 5\% some years (Briand et al., 2005). (ii) Fragmentation by human-induced obstacles can impact upstream migration (Drouineau et al., 2015; Tremblay et al., 2016). By blocking individuals during their upstream migration, they confine them into restricted parts of river basins (Kettle et al., 2011). (iii) During downstream migration, they can impair migration to the sea (Drouineau et al., 2017; Tremblay et al., 2016), especially because of mortality induced by passage through hydropower facilities (Pedersen et al., 2012; Winter et al., 2006). (iv) Finally, silver eel fishing is a widespread activity (Aalto et al., 2016; Amilhat et al., 2008; Bernotas et al., 2016; Verreault et al., 2012; Westerberg and Wickström, 2016) that targets large silvers when they migrate back to sea.

We adapted the GenEveel model and developed five output indicators (number of escapees, proportion of females, egg production, length-at-silvering, and proportion of slow growers) to consider the impact of anthropogenic pressures on population dynamics. We carried out a numerical exploration of the model and fitted statistical models to assess the effects of the anthropogenic pressures on the outputs. This enables us to quantify the impact of pressures on the different components and to discuss the implications.

\section{Materials and methods}

\subsection{GenEveel}

GenEveel is an individual-based model. It postulates that the population is composed of two types of individuals (slow and fast growing) based on a genetic polymorphism and that individuals determine their sex and select their growth habitat and length-at-silvering to optimize their fitness. Assuming that males follow a time-minimizing strategy, their fitness is assumed to be proportional to their survival rate until a constant length-at-silvering is reached. On the other hand, females are assumed to follow a size-maximizing strategy, and their fitness is constrained by a trade-off between fecundity at length-at-silvering and the survival rate to this length, with the length-atsilvering selected to optimize this trade-off. Growth is assumed to be a combination of intrinsic growth rates (slow and fast growers) modulated by environmental effects, with faster growth rates in downstream habitats. Survival is a product of environmental effects and density dependence.

The environment, a single river catchment, is represented by 30 contiguous cells (growth habitat) with prespecified effects on individual growth and mortality rates. One by one, individuals determine their sex and select their growth habitat and length-at-silvering based on the combination that maximizes fitness.

A complete description of the model can be found in Mateo et al. (in press). We parameterized the model as in the reference simulation in Mateo et al. (in press) for this study, which consisted of the best set of values found in the literature for the European eel. Seventeen parameters were used in the model to characterize the environment (as cells in the river catchment) and individuals (demographic, growth and fitness parameters).

\subsection{Impacts of anthropogenic pressures}

\subsubsection{Glass eel fishery}

The glass eel fishery was characterized by the catch rate, $g$, i.e., the proportion of individuals caught by the fishery. The glass eel fishery was assumed to harvest individuals before sex determination and habitat selection. Consequently, if $N$ eels entered the catchment, glass eel catches were assumed to follow a binomial distribution, $\operatorname{binomial}(N, g)$, and the number of survivors was the complement.

\subsubsection{Obstacles to upstream migration}

We used two obstacles $(0.66$ and 0.1 , respectively, according to the relative distance along the river and referring to the $20^{\text {th }}$ and $3^{\text {th }}$ cells of the 30 that represent the river catchment) characterized 
by their blockage rates $\left(b_{0.66}\right.$ and $b_{0.1}$, respectively) and locations ( $p o_{0.66}$ and $p o_{0.1}$, respectively, which represent cells of the catchments). For each individual, we restricted the possible combinations of growth habitat, length-at-silvering and sex to cells near the river mouth, $p o_{0.1}$, with a probability $b_{0.1}$ and to cells near the river source, $p o_{0.66}$, with probability $\left(1-b_{0.1}\right) \cdot\left(1-b_{0.66}\right)$.

\subsubsection{Turbine mortality}

The two obstacles also had turbine mortality rates ( $t_{0.66}$ and $t_{0.1}$, respectively). Each individual located upstream of the obstacle and that survived until length-at-silvering were killed by turbines, with a probability corresponding to the mortality rates.

\subsubsection{Silver eel fishery}

The silver eel fishery was assumed to affect eels in a similar way to the mortality due to turbines. We assumed that two successive silver eel fisheries occur, one located near the river source at position $p s_{0.66}$ and one near the river mouth at position $p s_{0.1}$. These fisheries were characterized by catch rates of $s_{0.66}$ and $s_{0.1}$, respectively. Each individual located upstream of the obstacle and that survived until length-at-silvering were caught by silver eel fisheries with a probability corresponding to the catch rates.

\subsection{Model sequence}

The glass eel fishery occurred first, as it is the first source of mortality encountered by young eels. Then, GenEveel was used to position individuals in the catchment with restrictions due to obstacles to determine their sex, length-at-silvering and survival probability to length-at-silvering. The survivors that reached maturity in the upper parts of the river migrated downstream and were impacted by the silver eel fishery and the turbine located near the river source. The remaining fish were then impacted by the silver eel fishery and the turbine located near the river mouth.

Fig, 1 represents the model sequence. A proportion, $g$, of recruits was first harvested by the glass eel fishery. Among the 1-g individuals that escaped the glass eel fishery, a proportion, $b_{0.1}$, was constrained to settle downstream of the first obstacle, and only $\left(1-b_{0.1}\right) \cdot\left(1-b_{0.66}\right)$ were free to settle in the whole catchment. After sex determination and habitat selection (the combination that maximized the expected fitness), individuals underwent downstream migration and were harvested with a given probability if they passed a silver eel fishery or a turbine.

We computed five indicators based on the survivors (escapees):

1. number of escapees $(N s)$;

2. mean length-at-silvering $(L s)$;

3. proportion of females (sex ratio) $(S R)$;

4. egg production (sum of female fecundity among survivors) (E); and

5. proportion of slow growers $(S l)$

The first indicator is the traditional indicator for quantifying mortality and is generally used as a proxy of the spawning biomass, although not accounting for trait modifications. The next two indicators aim to measure the effect of anthropogenic pressures on two plastic traits. The fourth indicator quantifies the total effects of pressures on egg production and is a more direct proxy than the number of escapees because it combines both induced mortality and trait modifications. The last indicator is used to quantify the selective pressure induced by each anthropogenic pressure.

\subsection{Numerical exploration of the model and results analysis}

\subsubsection{Experimental design}

Our objective was to compare the intensity of effects of anthropogenic pressures rather than locations. Therefore, we chose a set of parameters that were similar among pressures. For locations, pressure positions were set at the same cells in the catchment: $p s_{0.66}=p o_{0.66}=20$ and $p s_{0.1}=p o_{0.1}=3$. To explore the effect of pressure intensity, we used Latin hypercube sampling (LHS) (Iman and Conover, 1980; McKay, 1988; McKay et al., 2000). LHS is classical tool used to carry out global 
sensitivity analysis of models (Blower and Dowlatabadi, 1994; Helton et al., 2005; Helton and Davis, 2003; Manache and Melching, 2004). It allows an efficient exploration of the input parameter space; estimation of output statistics, such as sensitivity indices; and variance decomposition. It subdivides each parameter into $\mathrm{X}$ intervals and then samples those intervals with probability $1 / \mathrm{X}$ (random sampling within intervals), ensuring that each parameter interval is sampled only once and that two parameters are not sampled in the same interval in the same experiment. By doing this, LHS ensures a random association of parameter values and allows their respective effects to be disentangled.

In our LHS, the resulting design matrix is made up of all anthropogenic pressures $\left(g, b_{0.66}, b_{0.1}\right.$, $\left.s_{0.66}, s_{0.1}, t_{0.66}, t_{0.1}\right)$ in columns, defined at an interval of 0 (no pressure) to 1 (impact all individuals). Intervals were then subdivided into 100 subintervals, corresponding to simulations in rows. We built 100 independent LHSs to account for model stochasticity, resulting in 10,000 simulations.

\subsubsection{Results analysis}

For each output Y, we fitted a generalized additive model on the 10,000 simulations using $\mathrm{Y}$ as a dependent variable and the anthropogenic pressures $\left(g, b_{0.66}, b_{0.1}, s_{0.66}, s_{0.1}, t_{0.66}, t_{0.1}\right)$ as explanatory variables:

$$
\mathrm{Y} \sim \mathrm{s}(g)+\mathrm{s}\left(s_{0.1}\right)+\mathrm{s}\left(s_{0.66}\right)+\mathrm{s}\left(b_{0.1}\right)+\mathrm{s}\left(b_{0.66}\right)+\mathrm{s}\left(t_{0.1}\right)+\mathrm{s}\left(t_{0.66}\right)
$$

with $\mathrm{s}()$ as a smoother function.

The Gaussian family was used for the number of escapees $(N s)$, length-at-silvering $(L s)$ and egg production $(E)$ (a $\log$ transformation was used for $N s$ and $E$ to normalize the distribution), while the binomial family was used for the proportion of females $(S R)$ and slow growers $(S l)$.

Generalized additive models (GAMs) were fitted using the package mgcv (Wood, 2011) in R (R Development Core Team, 2011). Plots of marginal effects were used to explore the relations between pressures and outputs. The signs of the regression coefficients indicated whether the pressure has a positive or negative impact on the indicator. The proportion of explained variance was used to compare the strength of the effects of anthropogenic pressures.

We computed the partial rank correlation coefficients (PRCC) (Saltelli et al., 2000) to assess the global effects of pressures on each output variable using the package sensitivity (Pujol et al., 2016). These coefficients assessed the degree of association between an output variable and a predictor after removing the effects of other predictors.

\section{Results}

The PRCC are summarized in Table 1. The glass eel fishery had the most important influence; it had negative effects on the number of escapees and positive effects on the length-at-silvering and the proportion of females. Its influence was more limited on egg production (negative effects) and the proportion of slow growers (positive effects). Regarding egg production, the silver eel fishery and turbine located near the river mouth had negative effects that were similar to that of the glass eel fishery. Unsurprisingly, they also had important negative effects on the proportion of slow growers, the mean length-at-silvering and the number of escapees. Obstacles located near the river mouth had a great influence on all indicators except egg production; they had negative effects on the length-at-silvering and the proportion of females and positive effects on the number of escapees and the proportion of slow growers. The turbine and silver eel fishery located near the river source had lesser influences on the model outputs than the rest of the pressures.

The GAM summaries are presented in Table A1. All pressures had a negative impact on the number of escapees $(N s)$ except for obstacles located near the river mouth $\left(b_{0.1}\right)$, which had a positive impact (Table 1 - Fig. 2). Indeed, they blocked individuals in a zone with faster growth rates, decreasing the time to length-at-silvering and increasing the survival until escapement. Interestingly, the slope of the glass eel fishery effect was more moderate for small intensities than for strong intensities (Fig. 2). At low intensities, fisheries led to a decrease in density and therefore 
to lower density-dependent mortality and a higher survival rate of the remaining individuals, which balanced the effect of the fishery.

Regarding the proportion of females (Fig. 2 - Table 1), the glass eel fishery had the greatest impact by removing individuals. It drastically decreased the density and consequently the densitydependent mortality, favoring females, especially at high intensity (Fig. 2). The patterns were less obvious for the other pressures, except for obstacles located near the river mouth $\left(b_{0.1}\right)$; after a given level, an increasing blockage rate increased the density in downstream habitats, increasing the density-dependent mortality and favoring males (Fig. 2).

The effects of other pressures (turbines and the silver eel fishery) was not due to density dependence, but rather the distribution of individuals in the river catchment; there was a femalebiased sex ratio in the upstream habitat, and females were consequently more impacted by mortalities directed toward downstream migrants.

Regarding the length-at-silvering (Table 1 - Fig. 2), the results were very similar to the proportion of females since males have a constant and low length-at-silvering, while females have a variable and larger length-at-silvering. However, the effects of the silver eel fishery and the turbine located near the river mouth ( $s_{0.1}$ and $t_{0.1}$, respectively) were much more obvious.

Although obstacles located near the river mouth and the glass eel fishery $\left(b_{0.1}\right.$ and $g$, respectively) were the pressures most impacting the three first indicators, the silver eel fishery and the turbine located near the river mouth ( $s_{0.1}$ and $t_{0.1}$, respectively) had similar influences on egg production, and they were more important than the glass eel fishery $(g$ ) (Table 1$)$. Indeed, the effect of $g$ on the number of escapees was mitigated by the lower competition and the production of females in downstream zones of the catchment, explaining the flat effects observed for low $g$ (Fig. $2)$. For obstacles located near the river mouth $\left(b_{0.1}\right)$, the increase in the number of escapees explained an increase in egg production when blockage was low. However, for high blockage rates, the increase in escapees (Fig. 2) was outweighed by a higher proportion of males (Fig. 2), leading to a decrease in egg production (Fig. 2). For the silver eel fishery and the turbine located near the river mouth ( $s_{0.1}$ and $t_{0.1}$, respectively), their impacts on both the proportion of females and the number of escapees were negative, decreasing the effect on egg production.

Finally, the silver eel fishery and the turbine located near the river mouth decreased the proportion of slow growers because those individuals tended to settle in upstream habitats and were consequently more impacted than fast growers (Table 1 - Fig. 2). On the other hand, obstacles located near the river mouth tended to increase the proportion of slow growers; those individuals were blocked in downstream habitats where growth was faster, resulting in a better survival until length-at-silvering (as observed in the number of escapees $(N s)$, Fig. 2). However, blocked individuals were "constrained" to remain in downstream habitats, resulting in a decrease in their fitness and to strong competition with fast growers. Interestingly, the glass eel fishery, which harvested slow and fast growers equally, tended to favor fast growers at low intensities and slow growers at high intensities (Fig. 2; at high intensities, the very low density-dependent mortality strongly benefited slow growers by removing fast growers, which were dominant competitors).

\section{4. Discussion}

314 4.1. Assessing the impact of anthropogenic pressures: why consider other indicators than only the number of escapees?

The collapse in temperate eel populations required immediate actions (Dekker, 2009) to decrease all sources of anthropogenic pressures. This is the spirit of the European Regulation on the European eel and of subsequent eel management plans in European Union Member States. Logically, the first criteria used to assess the impact of anthropogenic pressures are mortality rates and escapement. However, given the large phenotypic variability observed at the distribution scale (Vélez-Espino and Koops, 2009), likely due to both phenotypic plasticity (Drouineau et al., 2014; Mateo et al., in press) and the consideration of genetic polymorphism (Côté et al., 2015), the 
number of escapees may not be sufficient, and it is worthwhile to explore the effects of anthropogenic pressures on other components. Thus, the aim of this study was to use the GenEveel model to explore the effects of different types of anthropogenic pressures on the number of escapees as well as other indicators accounting for life history traits and genetic polymorphism.

\subsection{Using a theoretical model to explore the possible consequences of anthropogenic pressures}

GenEveel is a theoretical model, but is parameterized with the best biological information available in the literature. Regarding the intensity, high levels have been observed for each type of pressure. For example, the exploitation rates of glass eels were found to be very high in some catchments: $13-30 \%$ in the Adour River (France) (Prouzet, 2002), 6.2-48.7\% in the Oria River (Spain) (Aranburu et al., 2016), 30.8-51.8\% in Nova Scotia (Jessop, 2000), 44.1-75\% in Shang-Chi (Taiwan) (Tzeng, 1984) and even 78.1-99.7\% in the Vilaine River (France) (Briand et al., 2005). The passability for upstream migration was estimated to range between 19.8 and $49.1 \%$ for an obstacle in the Canal des Etangs (France) (Drouineau et al., 2015). A similar result was obtained by Briand et al. (2005), who calculated an efficiency of the trapping ladder as $30 \%$ in the Vilaine catchment (France). Passability is probably even lower for obstacles not equipped with an eel ladder. Turbine impacts appear to vary considerably depending on study sites. On the Meuse River, Winter et al. (2007) estimated that the two hydropower plants induced an overall mortality of approximately 20-30\%. In a Swedish river, Calles et al. (2010) found mortality rates of $40 \%$ and $60 \%$ induced by two plants. At a Polish site, Dębowski et al. (2016) estimated a mortality rate of $55 \%$. Mortality due to silver eel fisheries also varies from 22-26\% in the Meuse River (Netherlands) (Winter et al., 2006) to $82 \%$ mortality in the Gudenaa River and Randers Fjord (Denmark) (Aarestrup et al., 2008) and can reach even higher levels in some Mediterranean lagoons (Amilhat et al., 2008).

Given the large variability in the pressure intensities, and the fact that they vary at the distribution area scale, we used a Latin hypercube sampling design to carry out the global exploration of their effects in a theoretical catchment in GenEveel. Consequently, the exercise is clearly theoretical, and our raw results should not be used to classify the effects of anthropogenic pressures. However, they provide valuable insights on the type of effects induced by the different pressures and indicate that the significance of these effects greatly depends on the considered output indicator.

We did not consider the effects of yellow eel fisheries in this exercise for various reasons. First, the GenEveel model did not describe the growth phase precisely, so it is difficult to incorporate such mortalities. Moreover, most of the pressures occur in specific parts of the catchments (the estuary for glass eel fisheries, obstacles one after another) and at a specific times (migration), while yellow eel fisheries are more widespread and occur all along the growth phase, so comparisons of these pressures would be more uncertain.

\subsection{The effect of anthropogenic pressures depends on their location within the catchment}

Among the most obvious results, the impacts of anthropogenic pressures clearly depend on their location in the river catchment, and pressures located in the very upper parts of the catchment, where densities are low, have limited impacts. Although this result is obvious, its consequence at the population scale is less obvious because anthropogenic activities are not uniformly distributed across the distribution area. For example, in Europe, some hydropower facilities can be found in downstream areas of river catchments, similar to in Scandinavia, while they are located upstream in France. Silver eel fisheries are mainly located in Scandinavia and the Mediterranean Sea (Dekker, 2003b), while glass eel fisheries are dominant in France and Spain. Since life history patterns and differences in densities are also observed at the distribution area scale, it is very difficult to draw up an overall picture of the effect of each individual pressure at the population scale.

\subsection{Effect of pressures on escapement: existence of compensatory mechanisms}


Another important message is that the number of escapees and the resulting egg production are not necessarily correlated. In our simulations, glass eel fisheries and migratory obstacles had the greatest influence on the number of escapees, the sex ratio and the length-at-silvering (although the effects were different depending on pressures). Nevertheless, the silver eel fishery and turbine mortality had similar negative impacts on egg production, which were greater than that of the glass eel fishery and were more significant than those of obstacles. This is explained by compensatory mechanisms that mitigate the negative effects of glass eel fisheries and obstacles to upstream migration, while there are no such mechanisms for those of silver eel fisheries and turbine mortality. For example, the decrease in escapement induced by the glass eel fishery can be compensated by the higher production of females. For obstacles to upstream migration, the decrease in female production is compensated by the better survival of individuals and consequently an increase in escapement. In other words, the pressure inducing the highest direct mortality does not necessarily have the greatest influence on silver eel escapement. Even pressures that do not induce any direct mortality, such as migratory obstacles, can influence some demographic attributes of escapees, such as the proportion of females or length-at-silvering. For example, obstacles close to the river mouth blocked individuals during their upstream migration in downstream habitats. As a consequence, slow growers that usually tend to settle in upstream habitats are forced to settle in downstream habitats with a faster growth rate and higher mortality due to competition. In these conditions, slow growers become males with a time-minimizing strategy, while they would have turned into females with a size-maximizing strategy in upstream habitats; this is why the proportion of females decreased. Since growth is fast in downstream habitats and those individuals mature very early (at male length-at-silvering), they have a higher survival rate until silvering than they would have known in upstream habitats, leading to an increase in the proportion of slow growers. However, they would have had higher fitness as a female in upstream habitats since the loss in survival would have been compensated by high fecundity.

Interestingly, by decreasing the number of individuals that enter the river catchment, a simulation with a glass eel fishery "mimics" a simulation with a depleted population. It is interesting to note that in such a situation, a decrease in competition enables individuals to settle in downstream habitats, where growth is faster. More females are also produced because of these lower densities. As a result, egg production is less impacted than the number of escapees. As such, the phenotypic plasticity of eels can be considered as a resilience factor in a depleted population.

\subsection{Anthropogenic pressures as selective pressures}

The final output of the model is the impact of anthropogenic pressures on slow and fast growers. Most pressures, except for the glass eel fishery, tend to favor fast growers over slow growers, and as such, anthropogenic pressures can be selective pressures. The selective pressure induced by obstacles on elver migration has already been observed at the gene expression level (Podgorniak et al., 2015a, 2015b, 2016). If most anthropogenic activities act as several pressures favoring fast growers, we can wonder how slow growers were preserved by natural selection. A possible explanation may be due to gender differences. Males are predominantly fast growers, while females are both slow and fast growers (Côté et al., 2015; Mateo et al., in press), but slow-growing females have a larger length-at-silvering and greater fecundity than fast-growing females (Mateo et al., in press). In a high-abundance context, we can assume that males are fast growers, females are predominantly slow growers, and the two types are necessary. In a collapsed population, anthropogenic pressures tend to favor males and fast growers (Table 1), and egg production can become limiting. Consequently, the few remaining slow-growing females (which are less impacted by competition and can settle in downstream habitats) can become even more important, explaining their preservation to some extent. To validate this assumption, it would be interesting to carry out a similar simulation exercise at the population scale and with multiple generations to explore the impacts of anthropogenic pressures on the two types of individuals. Moreover, this would allow us 
420

421

422

423

424

425

426

427

428

429

430

431

432

433

434

435

436

437

438

439

440

441

442

443

444

445

446

447

448

449

450

451

452

453

\section{4}

455

456

457

458

459

460

461

462

463

464

465

466

467

468

to explore the assumption of spatially varying selection proposed by Gagnaire et al. (2012) and Côté et al. (2014) by simulating the arrival of slow and fast growers in random and contrasting river catchments, where they would suffer different mortalities and would consequently be more or less adapted.

Selective pressure due to fishing activities on exploited marine stocks has been demonstrated for many fish stocks (Law, 2000; Pinsky and Palumbi, 2014). A major collapse in abundance is required to reduce the overall genetic diversity. Since current recruitment is now less than $5 \%$ of historical recruitment and, for the American eel, recruitment has ceased in Lake Ontario and Upper SaintLawrence (Casselman, 2003), a loss of genetic diversity is not impossible This question of diversity at the individual level is crucial for eel conservation since it may contribute to population resilience through a storage and portfolio effect (Secor, 2015).

The misunderstanding of the effects of anthropogenic pressures also means that we poorly understand the effects of some mitigating measures. Stocking programs have been widely used (Couillard et al., 2014) and are still widely used by European countries (Brämick et al., 2016; Josset et al., 2016; Simon et al., 2013). However, by modifying densities and moving slow or fast growers into habitats where they are not adapted, such measures can have unexpected effects on escapement. Such observations were made in Canada, where eels were stocked in the Great Lakes, and the escapees produced were more similar to escapees from their original sites than to native silver eels from the Great Lakes (Couillard et al., 2014; Stacey et al., 2015). Exploring this issue with GenEveel by artificially "moving" individuals after their sex and growth habitat have been determined will bring new insights into the ways stocking programs can affect the whole population.

\subsection{Conclusion}

Our theoretical exercise provided new insights on the impact of anthropogenic pressures, both direct and indirect. Since this simulation exercise is purely theoretical and because of the spatial heterogeneity in both anthropogenic pressures and eel life history traits, it is impossible to promote any specific management measures, which should be chosen according to the local conditions. However, our results imply that managers and scientists should not only assess the quantity of escapees but also their quality. Quantifying human-induced mortalities and the effects of anthropogenic pressures on the number of escapees is a main priority, given the dramatic situation of the three temperate eel populations. However, further research to investigate the possible impacts of anthropogenic pressures on phenotypic changes in life history traits and consequently the reproductive output of the spawning stock will be required to achieve sustainable management of the species.

\section{Acknowledgements}

This study was supported by the Hynes project between Irstea and EDF R\&D. We would like to thank Christian Rigaud, Bruno Ernande, Martin Castonguay and Laurent Beaulaton for their participation in fruitful discussions. We acknowledge the two referees for their helpful comments.

\section{References}

Aalto, E., Capoccioni, F., Mas, J.T., Schiavina, M., Leone, C., Leo, G.D., Ciccotti, E., 2016. Quantifying 60 years of declining European eel (Anguilla anguilla L., 1758) fishery yields in Mediterranean coastal lagoons. ICES J. Mar. Sci. J. Cons. 73, 101-110. doi:10.1093/icesjms/fsv084

Aarestrup, K., Thorstad, E., Koed, A., Jepsen, N., Svendsen, J., Pedersen, M., Skov, C., Økland, F., 2008. Survival and behaviour of European silver eel in late freshwater and early marine phase during spring migration. Fish. Manag. Ecol. 15, 435-440.

Als, T.D., Hansen, M.M., Maes, G.E., Castonguay, M., Riemann, L., Aarestrup, K., Munk, P., Sparholt, H., Hanel, R., Bernatchez, L., 2011. All roads lead to home: panmixia of European eel in the Sargasso Sea. Mol. Ecol. 20, 1333-1346. doi:10.1111/j.1365-294X.2011.05011.x 
469

470

471

472

473

474

475

476

477

478

479

480

481

482

483

484

485

486

487

488

489

490

491

492

493

494

495

496

497

498

499

500

501

502

503

504

505

506

507

508

509

510

511

512

513

514

515

516

517

518

519

520

521

522

523

Amilhat, E., Farrugio, H., Lecomte-Finiger, R., Simon, G., Sasal, P., 2008. Silver eel population size and escapement in a Mediterranean lagoon: Bages-Sigean, France. Knowl. Manag. Aquat. Ecosyst. 390391, 5p1-5p11.

Arai, T., Chino, N., 2012. Diverse migration strategy between freshwater and seawater habitats in the freshwater eel genus Anguilla. J. Fish Biol. 81, 442-455.

Aranburu, A., Diaz, E., Briand, C., 2016. Glass eel recruitment and exploitation in a South European estuary (Oria Bay of Biscay). ICES J. Mar. Sci. 73, 111-121. doi:10.1093/icesjms/fsv116

Belpaire, C., Pujolar, J.M., Geeraerts, C., Maes, G.E., 2016. Contaminants in Eels and their Role in the Collapse of the Eel Stocks. Biol. Ecol. Anguillid Eels 225.

Bernotas, P., Vetemaa, M., Saks, L., Eschbaum, R., Verliin, A., Järvalt, A., 2016. Dynamics of European eel landings and stocks in the coastal waters of Estonia. ICES J. Mar. Sci. J. Cons. 73, 84-90. doi:10.1093/icesjms/fsv245

Blower, S.M., Dowlatabadi, H., 1994. Sensitivity and uncertainty analysis of complex models of disease transmission: an HIV model, as an example. Int. Stat. Rev. Int. Stat. 229-243.

Boivin, B., Castonguay, M., Audet, C., Pavey, S.A., Dionne, M., Bernatchez, L., 2015. How does salinity influence habitat selection and growth in juvenile American eels Anguilla rostrata? J. Fish Biol. 86, 765-784. doi:10.1111/jfb.12604

Brämick, U., Fladung, E., Simon, J., 2016. Stocking is essential to meet the silver eel escapement target in a river system with currently low natural recruitment. ICES J. Mar. Sci. J. Cons. 73, 91-100. doi:10.1093/icesjms/fsv113

Briand, C., Fatin, D., Feunteun, E., Fontenelle, G., 2005. Estimating the stock of glass eels in an estuary by mark-recapture experiments using vital dyes. Bull. Fr. Pèche Prot. Milieux Aquat. 378-379, 23-46. doi:10.1051/kmae:2005002

Byer, J.D., Lebeuf, M., Trottier, S., Raach, M., Alaee, M., Stephen Brown, R., Backus, S., Casselman, J.M., Hodson, P.V., 2015. Trends of persistent organic pollutants in American eel (Anguilla rostrata) from eastern Lake Ontario, Canada, and their potential effects on recruitment. Sci. Total Environ. 529, 231-242. doi:10.1016/j.scitotenv.2015.05.054

Cairns, D.K., Secor, D.A., Morrison, W.E., Hallett, J.A., 2009. Salinity-linked growth in anguillid eels and the paradox of temperate-zone catadromy. J. Fish Biol. 74, 2094-2114.

Cairns, D.K., Tremblay, V., Caron, F., Casselman, J.M., Verreault, G., Jessop, B.M., de Lafontaine, Y., Bradford, R.G., Verdon, R., Dumont, P., Mailhot, Y., Zhu, J., Mathers, A., Oliveira, K., Benhalima, K., Dietrich, J.P., Hallett, J.A., Lagacé, M., 2008. American eel abundance indicators in Canada (Canadian Data Report of Fisheries and Aquatic Sciences 1207 No. Canadian Data Report of Fisheries and Aquatic Sciences 1207). Oceans and Science Branch, Fisheries and Oceans Canada.

Calles, O., Olsson, I., Comoglio, C., Kemp, P., Blunden, L., Schmitz, M., Greenberg, L., 2010. Sizedependent mortality of migratory silver eels at a hydropower plant, and implications for escapement to the sea. Freshw. Biol. 55, 2167-2180.

Casselman, J.M. (2003) Dynamics of Resources of the American Eel, Anguilla rostrata: Declining Abundance in the 1990s. In: Eel Biology. (eds K. Aida, K. Tsukamoto and K. Yamauchi). Springer Japan, pp 255-274.

Castelnaud, G., 2000. Localisation de la pêche, effectifs de pêcheurs et production des espèces amphihalines dans les fleuves français. Bull. Fr. Pêche Piscic. 357/358, 439-460.

Castonguay, M., Hodson, P.V., Couillard, C.M., Eckersley, M.J., Dutil, J.D., Verreault, G., 1994. Why is recruitment of the American eel, Anguilla rostrata, declining in the St. Lawrence River and Gulf ? Can. J. Fish. Aquat. Sci. 51, 479-488.

Côté, C.L., Castonguay, M., McWilliam, K.S., Gordon, C., Bernatchez, L., 2014. In absence of local adaptation, plasticity and spatially varying selection rule: a view from genomic reaction norms in a panmictic species (Anguilla rostrata). BMC Genomics 15, 403. doi:10.1186/1471-2164-15-403

Côté, C.L., Castonguay, M., Verreault, G., Bernatchez, L., 2009. Differential effects of origin and salinity rearing conditions on growth of glass eels of the American eel Anguilla rostrata: implications for stocking programmes. J. Fish Biol. 74, 1934-1948. doi:10.1111/j.1095-8649.2009.02291.x

Côté, C.L., Pavey, S.A., Stacey, J.A., Pratt, T.C., Castonguay, M., Audet, C., Bernatchez, L., 2015. Growth, Female Size, and Sex Ratio Variability in American Eel of Different Origins in Both Controlled Conditions and the Wild: Implications for Stocking Programs. Trans. Am. Fish. Soc. 144, 246-257. doi:10.1080/00028487.2014.975841 
Couillard, C.M., Verreault, G., Dumont, P., Stanley, D., Threader, R.W., 2014. Assessment of Fat Reserves Adequacy in the First Migrant Silver American Eels of a Large-Scale Stocking Experiment. North Am. J. Fish. Manag. 34, 802-813. doi:10.1080/02755947.2014.920738

Daverat, F., Beaulaton, L., Poole, R., Lambert, P., Wickstrom, H., Andersson, J., Aprahamian, M., Hizem, B., Elie, P., Yalcin-Ozdilek, S., Gumus, A., 2012. One century of eel growth: changes and implications. Ecol. Freshw. Fish 21, 325-336.

Daverat, F., Limburg, K., Thibault, I., Shiao, J.-C., Dodson, J., Caron, F., Tzeng, W.-N., Iizuka, Y., Wickström, H., 2006. Phenotypic plasticity of habitat use by three temperate eel species, Anguilla anguilla, A. japonica and A. rostrata. Mar. Ecol. Prog. Ser. 308, 231-241.

Davey, A., Jellyman, D., 2005. Sex determination in freshwater eels and management options for manipulation of sex. Rev. Fish Biol. Fish. 15, 37-52.

Dębowski, P., Bernaś, R., Skóra, M., Morzuch, J., 2016. Mortality of silver eel (Anguilla anguilla) migrating downstream through a small hydroelectric plant on the Drawa River in northern Poland. Arch. Pol. Fish. 24, 69-75.

Dekker, W., 2009. Worldwide decline of eel resources necessitates immediate action. Quebec Declaration of Concern.

Dekker, W., 2003a. Did lack of spawners cause the collapse of the European eel, Anguilla anguilla? Fish. Manag. Ecol. 10, 365-376. doi:10.1111/j.1365-2400.2003.00352.x

Dekker, W., 2003b. Status of the European eel stock and fisheries, in: Eel Biology. Springer, pp. $237-254$.

Dekker, W., 2000. A Procrustean assessment of the European eel stock. ICES J. Mar. Sci. 57, 938-947. doi:10.1006/jmsc.2000.0581

Dekker, W., Casselman, J.M., 2014. The 2003 Québec Declaration of Concern About Eel Declines-11 Years Later: Are Eels Climbing Back up the Slippery Slope? Fisheries 39, $613-614$. doi:10.1080/03632415.2014.979342

Drouineau, H., Bau, F., Alric, A., Deligne, N., Gomes, P., Sagnes, P., 2017. Silver eel downstream migration in fragmented rivers: use of a Bayesian model to track movements triggering and duration. Aquat. Living Resour. 30, 1-19. doi: 10.1051/alr/2017003

Drouineau, H., Rigaud, C., Daverat, F., Lambert, P., 2014. EvEel (evolutionary ecology-based model for eel): a model to explore the role of phenotypic plasticity as an adaptive response of three temperate eels to spatially structured environments. Can. J. Fish. Aquat. Sci. 71, 1561-1571. doi:10.1139/cjfas-20140090

Drouineau, H., Rigaud, C., Laharanne, A., Fabre, R., Alric, A., Baran, P., 2015. Assessing the efficiency of an elver ladder using a multi-state mark-recapture model. River Res. Appl. 31, $291-300$. doi:10.1002/rra.2737

Dutil, J.-D., Dumont, P., Cairns, D.K., Galbraith, P.S., Verreault, G., Castonguay, M., Proulx, S., 2009. Anguilla rostrata glass eel migration and recruitment in the estuary and Gulf of St Lawrence. J. Fish Biol. 74, 1970-1984. doi:10.1111/j.1095-8649.2009.02292.x

Edeline, E., 2007. Adaptive phenotypic plasticity of eel diadromy. Mar. Ecol.-Prog. Ser. 341, $229-232$.

Ernande, B., Dieckmann, U., 2004. The evolution of phenotypic plasticity in spatially structured environments: Implications of intraspecific competition, plasticity costs and environmental characteristics. J Evol Biol 17, 613-628.

Feunteun, E., 2002. Management and restoration of European eel population (Anguilla anguilla): An impossible bargain. Ecol Eng 18, 575-591. doi:10.1016/S0925-8574(02)00021-6

Gagnaire, P.-A., Normandeau, E., Côté, C., Hansen, M.M., Bernatchez, L., 2012. The Genetic Consequences of Spatially Varying Selection in the Panmictic American Eel (Anguilla rostrata). Genetics 190, 725736. doi:10.1534/genetics.111.134825

Geffroy, B., 2012. Déterminisme environnemental du sexe chez l’Anguille Européenne Anguilla anguilla (Thèse de doctorat - spécialité physiologie et biologie des organismes-populations-interactions). Université de Pau et des pays de l’Adour - École docorale 211 sciences exactes et leurs applications.

Geffroy, B., Bardonnet, A., 2015. Sex differentiation and sex determination in eels: consequences for management. Fish Fish. n/a-n/a. doi:10.1111/faf.12113

Gotthard, K., Nylin, S., 1995. Adaptive Plasticity and Plasticity as an Adaptation: A Selective Review of Plasticity in Animal Morphology and Life History. Oikos 74, 3-17. doi:10.2307/3545669

Han, Y., Hung, C., Liao, Y., Tzeng, W., 2010. Population genetic structure of the Japanese eel Anguilla japonica: panmixia at spatial and temporal scales. Mar. Ecol. Prog. Ser. 401, $221-232$. 
Helfman, G., Bozeman, E., Brothers, E., 1984. Size, age, and sex of American eels in a Georgia river. Trans. Am. Fish. Soc. 113, 132-141.

Helfman, G., Facey, D.E., Stanton Hales Jr., L., Bozeman Jr., E.L., 1987. Reproductive ecology of the American eel. Am. Fish. Soc. Symp. 1, 42-56.

Helton, J.C., Davis, F.J., 2003. Latin hypercube sampling and the propagation of uncertainty in analyses of complex systems. Reliab. Eng. Syst. Saf. 81, 23-69.

Helton, J.C., Davis, F.J., Johnson, J.D., 2005. A comparison of uncertainty and sensitivity analysis results obtained with random and Latin hypercube sampling. Reliab. Eng. Syst. Saf. 89, 305-330.

ICES. 2016. Report of the Working Group on Eels (WGEEL), 15-22 September 2016, Cordoba, Spain. ICES CM 2016/ACOM:19. 107 pp.

Iman, R.L., Conover, W.J., 1980. Small sample sensitivity analysis techniques for computer models. with an application to risk assessment. Commun. Stat.-Theory Methods 9, 1749-1842.

Jacoby, D., Casselman, J.M., DeLucia, M., Hammerson, G.A., Gollock, M., 2014. Anguilla rostrata, in: The IUCN Red List of Threatened Species. Version 2014. http://www.iucnredlist.org.

Jacoby, D., Gollock, M., 2014a. Anguilla anguilla, in: The IUCN Red List of Threatened Species. Version 2014.2. http://www.iucnredlist.org.

Jacoby, D., Gollock, M., 2014b. Anguilla japonica, in: The IUCN Red List of Threatened Species. Version 2014.2. http://www.iucnredlist.org.

Jacoby, D.M.P., Casselman, J.M., Crook, V., DeLucia, M.-B., Ahn, H., Kaifu, K., Kurwie, T., Sasal, P., Silfvergrip, A.M.C., Smith, K.G., Uchida, K., Walker, A.M., Gollock, M.J., 2015. Synergistic patterns of threat and the challenges facing global anguillid eel conservation. Glob. Ecol. Conserv. 4, 321-333. doi:10.1016/j.gecco.2015.07.009

Jessop, B.M., 2000. Size, and exploitation rate by dip net fishery, of the run of American eel, Anguilla rostrata (LeSueur), elvers in the East River, Nova Scotia. Dana 12, 43-57.

Jessop, B.M., 1998. Geographic and seasonal variation in biological characteristics of American eel elvers in the Bay of Fundy area and on the Atlantic coast of Nova Scotia. Can. J. Zool. 76, 2172-2185. doi:10.1139/z98-169

Josset, Q., Trancart, T., Mazel, V., Charrier, F., Frotté, L., Acou, A., Feunteun, E., 2016. Pre-release processes influencing short-term mortality of glass eels in the French eel (Anguilla anguilla, Linnaeus 1758) stocking programme. ICES J. Mar. Sci. J. Cons. 73, 150-157. doi:10.1093/icesjms/fsv074

Kettle, A.J., Asbjørn Vøllestad, L., Wibig, J., 2011. Where once the eel and the elephant were together: decline of the European eel because of changing hydrology in southwest Europe and northwest Africa? Fish Fish. 12, 380-411. doi:10.1111/j.1467-2979.2010.00400.x

Kirk, R.S., 2003. The impact of Anguillicola crassus on European eels. Fish. Manag. Ecol. 10, 385-394.

Law, R. 2000. Fishing, selection, and phenotypic evolution. ICES J. Mar. Sci. 57, 659-668. doi:10.1006/jmsc.2000.0731

Levins, R., 1963. Theory of fitness in a heterogeneous environment. II. Developmental flexibility and niche selection. Amercian Nat. 47, 75-90.

Manache, G., Melching, C.S., 2004. Sensitivity analysis of a water-quality model using Latin hypercube sampling. J. Water Resour. Plan. Manag. 130, 232-242.

Mateo, M., Lambert, P., Tétard, S., Castonguay, M., Ernande, B., Drouineau, H., in press. Exploring phenotypic plasticity and spatially varying selection for the European eel: an evolutionary ecology based model. Can. J. Fish. Aquat. Sci. doi: 10.1139/cjfas-2016-0214

McCleave, J., 1993. Physical and behavioural controls on the oceanic distribution and migration of leptocephali. J Fish Biol 43, 243-273.

McKay, M.D., 1988. Sensitivity and uncertainty analysis using a statistical sample of input values. Uncertain. Anal. 145-186.

McKay, M.D., Beckman, R.J., Conover, W.J., 2000. A comparison of three methods for selecting values of input variables in the analysis of output from a computer code. Technometrics 42, 55-61.

Melià, P., Bevacqua, D., Crivelli, A.J., De Leo, G.A., Panfili, J., Gatto, M., 2006. Age and growth of Anguilla anguilla in the Camargue lagoons. J. Fish Biol. 68, 876-890. doi:10.1111/j.0022-1112.2006.00975.x

Oliveira, K., 1999. Life history characteristics and strategies of the American eel, Anguilla rostrata 56, 795802.

Oliveira, K., Mccleave, J., 2000. Variation in population and life history traits of the American eel, Anguilla 
rostrata, in four rivers in Maine. Env. Biol Fishes 59, 141-151.

Pedersen, M.I., Jepsen, N., Aarestrup, K., Koed, A., Pedersen, S., Okland, F., 2012. Loss of European silver eel passing a hydropower station. J. Appl. Ichthyol. 28, 189-193.

Pigliucci, M., 2005. Evolution of phenotypic plasticity: Where are we going now? Trends Ecol Evol 20, 481486.

Pinsky, M.L., Palumbi, S.T., 2014. Meta-analysis reveals lower genetic diversity in overfished populations. Mol. Ecol. 23, 29-39. doi: 10.1111/mec.12509

Podgorniak, T., Angelini, A., Blanchet, S., de Oliveira, E., Pierron, F., Daverat, F., 2015. Climbing experience in glass eels: A cognitive task or a matter of physical capacities? Physiol. Behav. 151, 448-455. doi:10.1016/j.physbeh.2015.08.001

Podgorniak, T., Blanchet, S., de, O., Daverat, F., Pierron, F., 2016. To boldly climb: Behavioural and cognitive differences in migrating European glass eels. R. Soc. Open Sci. 3. doi:10.1098/rsos.150665

Podgorniak, T., Milan, M., Pujolar, J.M., Maes, G.E., Bargelloni, L., De Oliveira, E., Pierron, F., Daverat, F., 2015. Differences in brain gene transcription profiles advocate for an important role of cognitive function in upstream migration and water obstacles crossing in European eel. BMC Genomics 16, 378. doi:10.1186/s12864-015-1589-y

Prouzet, P., 2002. Historique des captures de civelles, intensité actuelle de leur exploitation, variation de leur capturabilité par la pêche professionnelle maritime et indice de colonisation sur le bassin versant de l'Adour (Rapport final, contrat EC/DG FISH (DGXIV) N No. Rapport final, contrat EC/DG FISH (DGXIV) N).

Pujol, G., Iooss, B., Boumhaout, A.J. with contributions from K., Veiga, S.D., Fruth, J., Gilquin, L., Guillaume, J., Gratiet, L.L., Lemaitre, P., Ramos, B., Touati, T., Weber, F., 2016. sensitivity: Global Sensitivity Analysis of Model Outputs.

Pujolar, J.M., 2013. Conclusive evidence for panmixia in the American eel. Mol. Ecol. 22, 1761-1762. doi:10.1111/mec.12143

Pujolar, J.M., Jacobsen, M.W., Als, T.D., Frydenberg, J., Munch, K., Jónsson, B., Jian, J.B., Cheng, L., Maes, G.E., Bernatchez, L., others, 2014. Genome-wide single-generation signatures of local selection in the panmictic European eel. Mol. Ecol. 23, 2514-2528.

R Development Core Team, 2011. R: A Language and Environment for Statistical Computing.

Saltelli, A., Chan, K., Scott, E.M., others, 2000. Sensitivity analysis. Wiley New York.

Schmidt, J., 1923. Breeding places and migrations of the eel. Nature 111, 51-54.

Secor, D.H., 2015. American Eel: When Does Diversity Matter? Fisheries 40, 462-463. doi:10.1080/03632415.2015.1073152

Simon, J., Dörner, H., Scott, R.D., Schreckenbach, K., Knösche, R., 2013. Comparison of growth and condition of European eels stocked as glass and farm sourced eels in lakes in the first 4 years after stocking. J. Appl. Ichthyol. 29, 323-330. doi:10.1111/jai.12078

Stacey, J.A., Pratt, T.C., Verreault, G., Fox, M.G., 2015. A caution for conservation stocking as an approach for recovering Atlantic eels. Aquat. Conserv. Mar. Freshw. Ecosyst. 25, 569-580. doi:10.1002/aqc.2498

Tatsukawa, K., 2003. Eel Resources in East Asia, in: Aida, K., Tsukamoto, K., Yamauchi, K. (Eds.), Eel Biology. Springer Japan, pp. 293-298.

Tesch, F.W., 2003. The Eel. Blackwell Publishing.

Tremblay, V., Cossette, C., Dutil, J.-D., Verreault, G., Dumont, P., 2016. Assessment of upstream and downstream passability for eel at dams. ICES J. Mar. Sci. J. Cons. 73, 22-32. doi:10.1093/icesjms/fsv106

Tsukamoto, K., 1992. Discovery of the spawning area for Japanese eel. Nature 356, 789-791. doi:10.1038/356789a0

Tsukamoto, K., Nakai, I., Tesch, W.-V., 1998. Do all freshwater eels migrate? [3]. Nature 396, 635-636.

Tzeng, W.-N., 1984. An estimate of the exploitation rate of Anguilla japonica elvers immigrating into the coastal waters off Shuang-Chi River, Taiwan. Bull. Inst. Zool. Acad. Sin. 23, 173-180.

Ulrik, M.G., Pujolar, J.M., Ferchaud, A.-L., Jacobsen, M.W., Als, T.D., Gagnaire, P.A., Frydenberg, J., Bøcher, P.K., Jónsson, B., Bernatchez, L., Hansen, M.M., 2014. Do North Atlantic eels show parallel patterns of spatially varying selection? BMC Evol. Biol. 14, 138. doi:10.1186/1471-2148-14-138

Van Den Thillart, G., Palstra, A., Van Ginneken, V., 2007. Simulated migration of European silver eel; swim capacity and cost of transport. J. Mar. Sci. Technol. 15, 1-16. 
689

Vélez-Espino, L.A., Koops, M.A., 2009. A synthesis of the ecological processes influencing variation in life history and movement patterns of American eel: towards a global assessment. Rev. Fish Biol. Fish. 20, 163-186. doi:10.1007/s11160-009-9127-0

Verreault, G., Mingelbier, M., Dumont, P., 2012. Spawning migration of American eel Anguilla rostrata from pristine (1843-1872) to contemporary (1963-1990) periods in the St Lawrence Estuary, Canada. J. Fish Biol. 81, 387-407.

Vollestad, L.A., 1992. Geographic variation in age and length at metamorphosis of maturing European eel Environmental effects and phenotypic plasticity 61, 41-48.

Westerberg, H., Wickström, H., 2016. Stock assessment of eels in the Baltic: reconciling survey estimates to achieve quantitative analysis. ICES J. Mar. Sci. J. Cons. 73, 75-83. doi:10.1093/icesjms/fsv049

White, J.W., Rassweiler, A., Samhouri, J.F., Stier, A.C., White, C., 2014. Ecologists should not use statistical significance tests to interpret simulation model results. Oikos 123, 385-388. doi:10.1111/j.16000706.2013.01073.x

Winter, H., Jansen, H., Breukelaar, A., 2007. Silver eel mortality during downstream migration in the River Meuse, from a population perspective. ICES J. Mar. Sci. 64, 1444-1449.

Winter, H., Jansen, H., Bruijs, M., 2006. Assessing the impact of hydropower and fisheries on downstream migrating silver eel, Anguilla anguilla, by telemetry in the River Meuse. Ecol. Freshw. Fish 15, 221228.

Wood, S.N., 2011. Fast stable restricted maximum likelihood and marginal likelihood estimation of semiparametric generalized linear models. J. R. Stat. Soc. Ser. B Stat. Methodol. 73, 3-36. 


\section{Tables}

710 Table 1. Partial rank correlation coefficients between output variables (columns) and pressures (rows). A 711 positive coefficient indicates a positive correlation. $g$ : glass eel fishery, $s_{0.66}$ : silver eel fishery located near 712 the river source, $s_{0.1}$ : silver eel fishery located near the river mouth, $t_{0.66}$ : turbine located near the river source, $713 t_{0.1}$ : turbine located near the river mouth, $b_{0.66}$ : obstacle to upstream migration, $b_{0.1}$ : obstacle to downstream 714 migration.

\begin{tabular}{llllll}
\hline & $N s$ & $L s$ & $S R$ & $E$ & $S l$ \\
$g$ & -0.95 & 0.94 & 0.95 & -0.49 & 0.22 \\
$b_{0.1}$ & 0.77 & -0.75 & -0.57 & -0.01 & 0.88 \\
$b_{0.66}$ & 0.02 & 0 & 0.01 & 0.01 & 0.02 \\
$s_{0.1}$ & -0.39 & -0.33 & -0.14 & -0.42 & -0.35 \\
$s_{0.66}$ & -0.02 & 0 & 0.01 & -0.01 & -0.03 \\
$t_{0.1}$ & -0.39 & -0.33 & -0.12 & -0.4 & -0.35 \\
$t_{0.66}$ & -0.01 & -0.02 & -0.01 & -0.01 & -0.01 \\
\hline
\end{tabular}




\section{Figures}

(1)

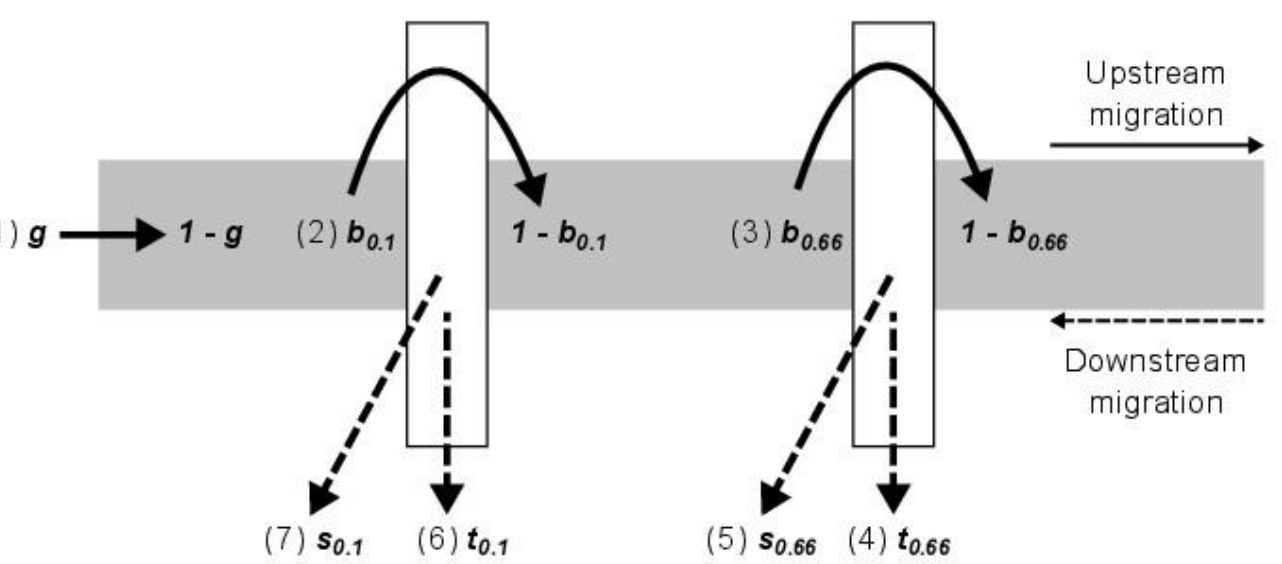

(2)

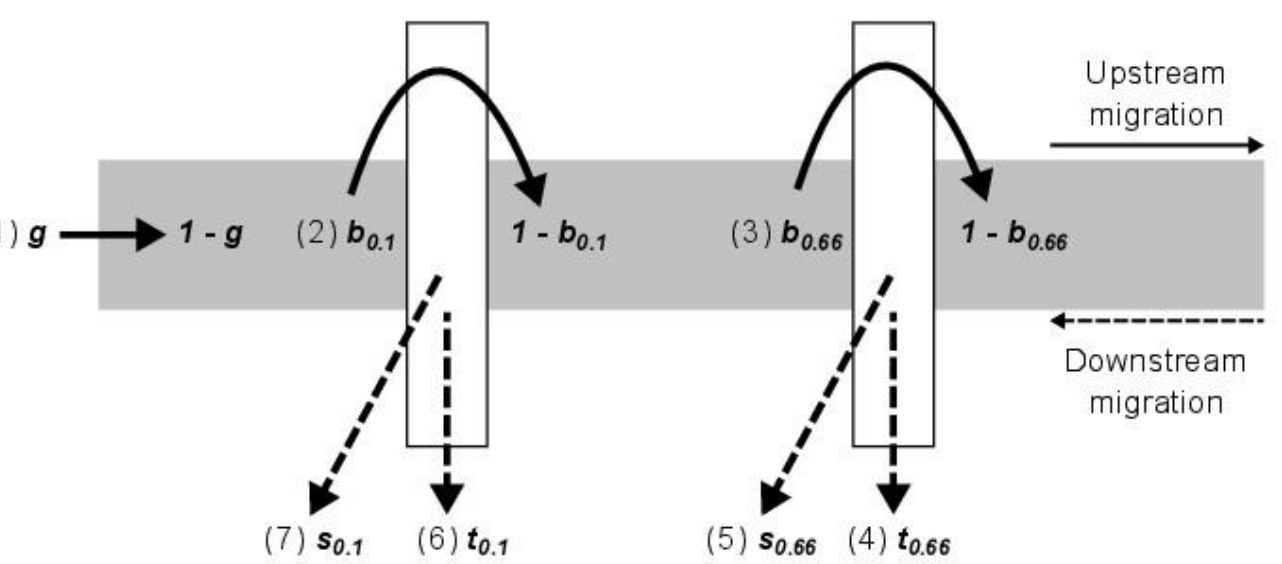

(7) $s_{0.1}$

719 Figure 1. Conceptual representation of the catchment, indicating the seven anthropogenic pressures considered in the study: 1) $g$ : catch rate by the glass eel fishery, 2) $b_{0.66}$ and 3) $b_{0.1}$ : blockage rates (located near the river source and the river mouth, respectively), 4) $t_{0.66}$ and 6) $t_{0.1}$ : turbine mortality rates (located near the river source and the river mouth, respectively), 5) $s_{0.66}$ and 7) $s_{0.1}$ : catch rates by the silver eel fisheries (located near the river source and the river mouth, respectively). 

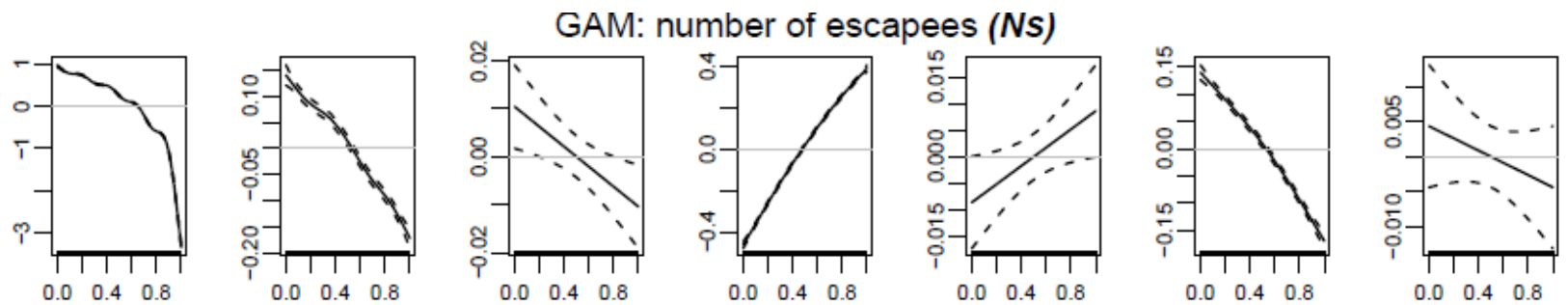

GAM: proportion of females (SR)
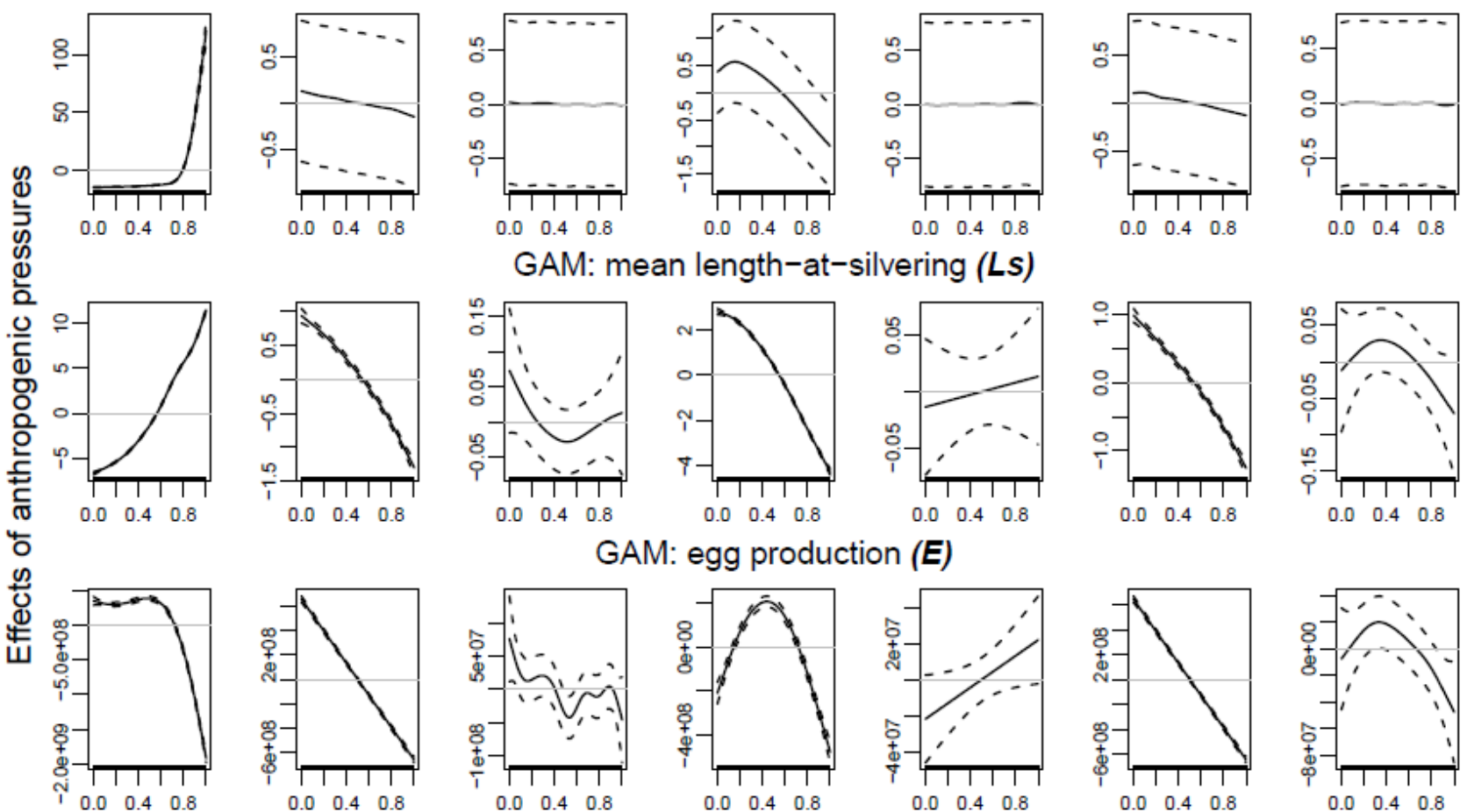

GAM: mean length-at-silvering (Ls)
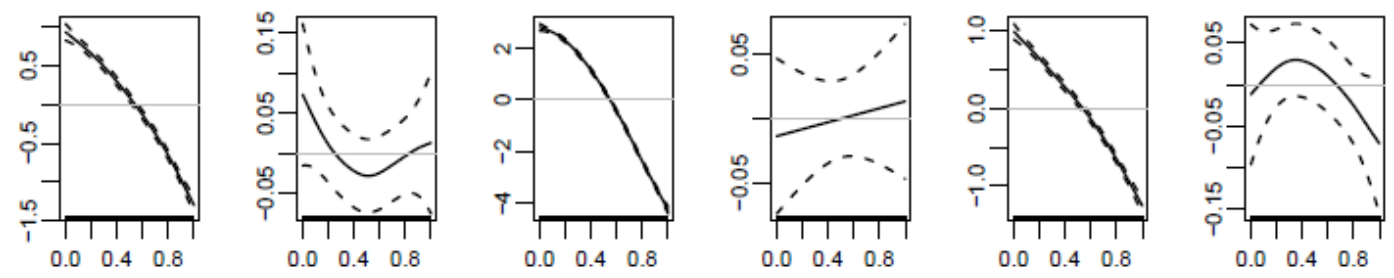

GAM: egg production (E)
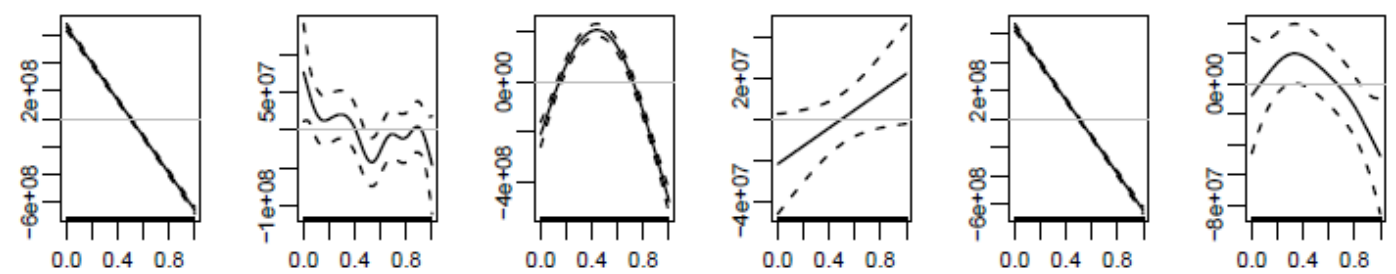

GAM: proportion of slow growers (SI)
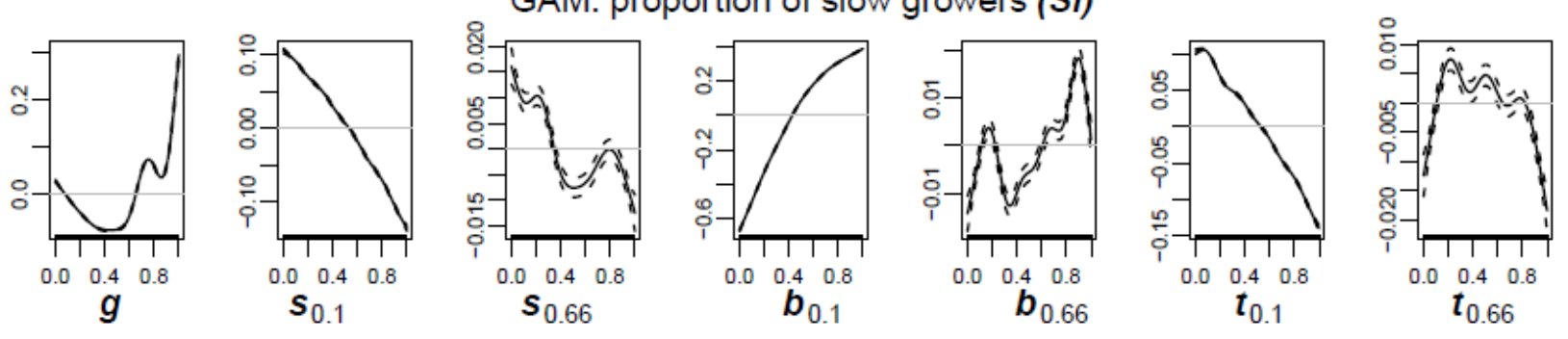

Figure 2. Effects of the pressures on the five indicators estimated by the GAMs. $g$ : glass eel fishery, $s_{0.66}$ and $s_{0.1}$ : silver eel fisheries located near the river source and the river mouth, respectively, $t_{0.66}$ and $t_{0.1}$ : turbines located near the river source and the river mouth, respectively, $b_{0.66}$ and $b_{0.1}$ : obstacles located near the river 730 source and the river mouth, respectively. 


\section{Supplementary data}

732 Table A1. Summary of the GAM model. edf corresponds to the estimated degrees of freedom for each model 733 parameter. F corresponds to the Fisher statistics when the Gaussian family is used and Chis.sq to the $\chi^{2}$ 734 statistics when the binomial family is used. P-values are not presented (although all are smaller than 0.05) 735 because significance tests are not recommended when analyzing simulation model results (White et al., 736 2014).

\begin{tabular}{|c|c|c|c|c|c|c|c|c|c|c|}
\hline & Ns & & $L s$ & & $S R$ & & $E$ & & $S l$ & \\
\hline & edf & $\mathrm{F}$ & edf & $\mathrm{F}$ & edf & Chi.sq & edf & $\mathrm{F}$ & edf & Chi.sq \\
\hline$s(g)$ & 9 & 18517.8 & 8.6 & 14036.4 & 9.0 & 3849436.9 & 6.6 & 1257.1 & 9.0 & 231 \\
\hline $\mathrm{s}\left(\mathrm{s}_{0.1}\right)$ & 5.0 & 266.2 & 3.3 & 451.8 & 8.8 & 56266.4 & 1.0 & 3906.1 & 8.7 & 52527.1 \\
\hline$s\left(s_{0.66}\right)$ & 1.0 & 7.7 & 2.2 & 1.6 & 8.8 & 485.7 & 6.8 & 2.1 & 8.1 & 592.6 \\
\hline $\mathrm{s}\left(b_{0.1}\right)$ & 3.4 & 3066.9 & 5.2 & 3311.3 & 9.0 & 2598861.4 & 4.0 & 194.8 & 8.7 & 1001753.5 \\
\hline $\mathrm{s}\left(b_{0.66}\right)$ & 1.0 & 5.3 & 1.0 & 0.3 & 8.7 & 515.9 & 1.0 & 4.3 & 8.9 & 783.7 \\
\hline $\mathrm{s}\left(t_{0.1}\right)$ & 2.5 & 545.4 & 2.9 & 497.5 & 8.9 & 56169.5 & 1.0 & 3727.6 & 8.9 & 54605.7 \\
\hline $\mathrm{s}\left(t_{0.66}\right)$ & 1.0 & 1.3 & 2.0 & 2.0 & 8.9 & 541.1 & 2.5 & 3.3 & 8.0 & 357.9 \\
\hline
\end{tabular}

